\title{
ALPHABETICAL ORDER EFFECTS IN SCHOOL ADMISSIONS
}

\author{
Štěpán Jurajda \\ Daniel Münich
}

Charles University

Centerfor Economic Research and Graduate Education

Academy of Sciences of the Czech Republic

Ec onomics Institute
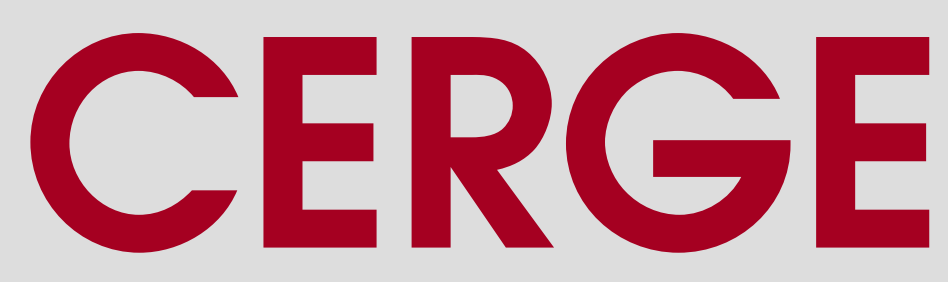

WORKING PAPER SERIES (ISSN 1211-3298)

Electronic Version 


\section{Working Paper Series \\ 509 (ISSN 1211-3298)}

\section{Alphabetical Order Effects in School Admissions}

Štěpán Jurajda

Daniel Münich

\section{CERGE-EI}

Prague, February 2014 
ISBN 978-80-7343-313-0 (Univerzita Karlova. Centrum pro ekonomický výzkum a doktorské studium)

ISBN 978-80-7344-306-1 (Akademie věd České republiky. Národohospodářský ústav) 


\title{
Alphabetical Order Effects in School Admissions
}

\author{
Štěpán Jurajda* and Daniel Münich \\ CERGE-EI, Charles University Prague and Academy of Sciences of the Czech Republic, \\ Politickych veznu 7, Prague 11121, Czech Republic.
}

February 17, 2014

\begin{abstract}
If school admission committees use alphabetically sorted lists of applicants in their evaluations, one's position in the alphabet according to last name initial may be important in determining access to selective schools. In Jurajda and Münich (2010) we provided evidence consistent with this hypothesis based on graduation exams taken in grade 13 in the Czech Republic: 'Z' students in selective schools had higher exam scores than 'A' students. In this paper, we use the TIMSS\&PIRLS test scores of 4 th graders and the PISA test scores of 8th and 9th graders in the Czech Republic to provide evidence on how the alphabetical sorting outcome we uncovered earlier arises during early tracking into selective schools. Using the PISA data, we also provide similar evidence for Denmark.
\end{abstract}

\begin{abstract}
Pokud komise rozhodující v rámci přijímacích řízení pracují se seznamy uchazečůn, které jsou řazeny podle abecedy, pořadí v abecedě může ovlivňovat pravděpodobnost přijetí. V práci Jurajda a Münich (2010) jsme předložili empirická zjištění vyplývající z analýzy celostátních maturitních testů, která byla v souladu s touto hypotézou: studenti s 'Z' příjmeními měli na výběrových školách lepší výsledky než studenti s 'A' př́íjmeními. V tomto článku využíváme dat TIMSS\&PIRLS o žácích čtvrtých tříd v ČR a dat PISA o žácích osmých a devátých tříd v ČR a v Dánsku a ukazujeme, jak toto abedecní třídění vzniká v rámci selekce studentů na výběrové školy.
\end{abstract}

JEL Codes: H49, J78, I29

Keywords: Admissions, Alphabetical order, Order effects, Early tracking

* Corresponding author. Tel.: +420 224005 139. E-mail: stepan.jurajda@cerge-ei.cz .

Acknowledgements CERGE-EI is a joint workplace of the Center for Economic Research and Graduate Education, Charles University, and the Economics Institute of the Academy of Sciences of the Czech Republic. Both authors are Research Affiliates at CEPR, London; Jurajda is also Research Fellow at IZA, Bonn. Miroslava Federičová provided excellent research assistance. While working on this paper, Š. Jurajda has been supported by the Karel Janeček Foundation. D. Münich gratefully acknowledges support from the Czech Science Foundation (grant P402/12/G130). 


\section{Introduction}

Decision science studies how rankings are generated by evaluators faced with many subjects to assess. University admissions officers, for example, interview hundreds of applicants each year as do recruiting managers in large companies. The literature identifies several behavioral biases in ranking generation. For example, Simonsohn and Gino (2013) analyze MBA admission decisions and show that they are based on comparing applicants only within narrow batches assessed within a day. Others follow Tversky and Kahneman (1971) and study the belief in the 'law of small numbers' whereupon having given a set of positive (negative) judgments, evaluators may expect a weaker (stronger) candidate to appear next. We consider behavioral consequences of the simple but natural possibility that lists of subjects to be evaluated, applicants to oversubscribed schools in our case, may be sorted alphabetically.

When school admissions are determined based on multiple qualitatively different criteria, i.e., in absence of a summarizing index of applicant quality, admission committees may work with alphabetically sorted spreadsheet files listing applicant characteristics. In such situations, applicants on the margin of admission who are sorted towards the top of an applicant lists may obtain a more favorable treatment compared to marginal applicants near the bottom of the list where constraints on the total number of possible admissions become binding. (Such practice would implicitly correspond to using the alphabet to 'randomize' admissions within a group of applicants close to the margin of admission.) Alphabetical order effect could also be present in schools that use oral exams or interviews and process applicants in alphabetical order.

In Jurajda and Münich (2010) we provided evidence consistent with this hypothesis based on the population of 1999 Czech secondary school graduation exams (taken by about 60\% of each cohort in grade 13) and all 1999 university applications. First, secondary school 
graduates with last names sorted towards the bottom of the alphabet scored better in exams than students with names sorted towards the top of the alphabet. Such a sorting pattern is consistent with ' $Z$ ' applicants on the margin of admission facing lower chances of admission into selective secondary schools. To see this point in a simple setting, suppose that students are of three ability types: high, medium, and low. If all high-ability students are admitted to selective programs, all low-ability students end up studying in programs that do not apply any selection, and if the medium types sorted low in the alphabet face lower chances of admission into selective schools, then there will be a positive correlation between students' ability and being sorted low in the alphabet within both the selective schools (thanks to medium-ability 'A' students) and the non-selective schools (thanks to medium-ability 'Z' students). ${ }^{1}$ Second, we used the graduation exam scores to identify marginal applications to universities and find that within the group of applications predicted to be on the margin of admission to a particular university program, those with ' $Z$ ' surnames were less likely to be offered admission than similar 'A' applications while there was no relationship between one's position in the alphabet according to last name initial and admission decisions for the most and least qualified university applicants.

However, since our evidence was based on data covering only 19-year-olds, we had no information on the potential relationship between one's position in the alphabet and one's ability or study results prior to any sorting into selective secondary schools. Thus our evidence, while strongly suggestive, remained inconclusive as we could not dismiss the hypothesis that a general relationship exists in the Czech Republic between last name initial and ability

\footnotetext{
${ }^{1}$ In Jurajda and Münich (2010) we discuss a more general, if still simple model of student-school matching where there is a group of indistinguishable applicants on the margin of admission thanks to either noisy admission exams or discrete support of the admission 'score' measure, and where the distribution of ability is assumed to be independent of one's position in the alphabet.
} 
prior to any early tracking. ${ }^{2}$ Further, both of our findings, i.e., the sorting patterns across secondary schools and the identification of marginal university applicants, were based on the 1999 secondary-school graduation exam, which was a pilot national exam conducted as a part of an effort to replace school-specific exams with a national system, and one may therefore want to examine the same hypothesis using more standard data. ${ }^{3}$

In this paper, we use the TIMSS\&PIRLS test scores of 4 th graders and the PISA test scores of 8th and 9th graders to provide evidence on whether early tracking can give rise to the alphabetical school sorting for 13 th graders we uncovered earlier. The timing of the TIMSS\&PIRLS survey closely precedes the first selection into specialized programs in the Czech Republic and thus allows us to ask about the presence of any general relationship of alphabetical sorting to student ability in absence of selective school admissions. The PISA sample of Czech 8th and 9th graders, which covers students in both all-inclusive lowersecondary programs and selective academic programs, then allows us to ask whether alphabetical sorting arises with school selection. Using PISA data, we also contrast alphabetical student sorting in the Czech Republic, where tracking into selective schools occurs in the 6th grade, with that in Denmark, where no selection occurs until the 9th grade, so that the PISA sample covers pupils both before and after selection takes place. Our findings, based on internationally comparable samples of pupils in two countries, are supportive of early tracking being the mechanism that gives rise to the cohort-wide alphabetical sorting pattern we uncovered earlier with population data on secondary-education students.

\footnotetext{
${ }^{2}$ We could also not rule out the possibility that studying in Czech secondary schools somehow favors the educational outcomes of 'Z' students. Students are not seated according to alphabetical order in Czech classrooms and we are aware of no mechanism that could generate such alphabetical learning biases.

${ }^{3}$ The national system was in fact not fully introduced until 2011 and has been subjected to several design changes since then.
} 
Our evidence is related to the extensive literature that studies order effects in many competitive settings including musical competitions where contestant order is drawn randomly (e.g., van Ours and Ginsburgh, 2003), elections where candidate order on ballots is often determined based on the alphabet (e.g., Ho and Imai, 2008), or scientific citations, which depend on the alphabetical order in which authors are listed (Einav and Yariv, 2006; Praag and Praag, 2008). Unlike a typical order-effect study, we do not show how alphabetical order effects operate in school admissions or even in which schools admission lists are sorted according to the alphabet, ${ }^{4}$ but we combine evidence from several data sources and education levels to build the case that such sorted lists are in use and that they affect admission decisions.

Given the omnipresent nature of alphabetical sorting, our evidence may also be important for the analysis of decision making in many settings outside of school admission decisions. Customers may select their service provider from the top of an alphabetically sorted directory, employers may be more attentive to job applicants who are interviewed first, access to oversubscribed public support may in part depend on one's alphabetical position, etc. The issue with the repeated use of the alphabet to provide a non-discriminatory sorting is that one's last-name-initial 'lottery ticket' is drawn once for life, i.e., for many potential lotteries. ${ }^{5}$

Our analysis is mainly based on the experience of students in the Czech Republic, which provides a useful case to study for three reasons. First, studying alphabetical sorting effects in admission procedures in the Czech Republic is motivated by anecdotal evidence discussed in Jurajda and Münich (2010). Second, the Czech education system features strong early tracking (OECD, 2010). Third, the country is highly homogenous as it has only a small

\footnotetext{
${ }^{4}$ Asking hundreds of schools about admission procedures they used several years ago was not feasible.

${ }^{5}$ In Jurajda and Münich (2010) we illustrate that the repeated use of alphabetical sorting at the entry to both secondary and tertiary education can lead to efficiency losses in matching students to schools.
} 
immigrant community ${ }^{6}$ and its only sizeable minority, the Roma, is effectively excluded from selective schools (Šimíková et al., 2004), such that the alphabetical comparisons we make here are unlikely to be contaminated by potentially different naming patterns of ethnic groups. In the Czech Republic, there are also no types of last names related to a history of family wealth such as "van" or "von" (Moldanová, 2004).

The paper is organized as follows. In the next section, we describe our data and use them to offer stylized facts about the Czech education system. Sections 3 and 4 present the test-score analysis based on the Czech 2011 TIMSS\&PIRLS sample and based on the Czech and Danish 2009 PISA sample, respectively. The last section concludes.

\section{Data and Education Systems}

The structure of the Czech educational system parallels those of other European countries (such as Denmark) with two exceptions: the country has traditionally had one of the highest rates of upper-secondary education attainment and one of the lowest rates of tertiary attainment in the OECD. The Czech education system also applies strong early tracking, similar to some other EU systems. The age at first selection, from elementary schools to eight-year academic programs that typically lead to university education, is eleven, similar to Austria, Belgium, or Germany. In contrast, several EU countries such as Finland, France, Poland, Spain, and the UK do not select students into separate tracks until age sixteen (OECD, 2010).

In 2009 Czech eight-year academic programs (so-called 'gymnazia') admitted $11 \%$ of 6 th graders (UIV, 2010), while the rest of the cohort stayed in all-inclusive lower-secondary edu-

${ }^{6}$ Only about 3 percent of inhabitants were born outside of the country, according to the Czech Statistical Office. We use the available indicators in the data to exclude students from immigrant families from our analysis. 
cation. ${ }^{7}$ In the same year in Denmark, about $10 \%$ of 9 th graders entered continuation schools ('Efterskoler') while the rest of the cohort stayed in all-inclusive lower-secondary programs. 'Efterskoler' are private residential (boarding) schools for pupils in grades 9 to 10 . These schools typically receive a substantial state subsidy and some of them are based on a specific philosophy, pedagogical approach, or religious belief, similar to the Czech 'gymnazia', which, however, are not residential. ${ }^{8}$ The 'gymnazia' programs, and to a lesser extent the 'Efterskoler' programs, enrol more talented students than all-inclusive schools, as we document below.

In this paper, we use pupil data from two international data-collection efforts: the 2011 Czech sample of 4th graders (aged 9 to 10) from the Trends in International Mathematics and Science Study \& Progress in International Reading Literacy Study (TIMSS\&PIRLS) and the 2009 Czech and Danish samples of 15-year-olds (in grade 8 and 9) from the Programme for International Student Assessment (PISA). Pupils in the Czech 4th grade and in the Danish 8th grade are not yet affected by selection into specialized programs and we can thus ask whether any correlation exists between their last name initials and their test scores prior to any selection. The PISA test scores of Czech 8th and 9th graders and of Danish 9th graders then allow us to ask whether alphabetical sorting is present after selection has taken place

\footnotetext{
${ }^{7} 5$ th graders can submit an unlimited number of applications to eight-year 'gymnazia' programs, but they are constrained by the geographical availability of such programs with a typical NUTS-4 district offering at most two. Some of these programs are private. The application process typically consists of a written exam administered independently by each school. Competition for entry is fierce, as only about half of applicants to these programs were admitted in 2010, according to data collected by the Ministry of Education of the Czech Republic. See Filer and Münich (2013) for a detailed description of the Czech education system.

${ }^{8}$ Historically, 'Efterskoler' catered to pupils who had encountered academic or personal problems in public education; however, this image has changed dramatically and these schools are now attended by an increasing number of teenagers who desire (or whose parents desire) a year or more away from home.
} 
with about one tenth of the cohort sorted into specialized programs. ${ }^{9}$

Our first source of information on 4th graders, the TIMSS survey, measures mathematics and science knowledge. It so happened that in 2011 the PIRLS survey, which measures reading comprehension of 4th graders, was conducted jointly with TIMSS so that all three test scores are available for the joint sample. ${ }^{10}$ Fortunately for our analysis, the TIMSS\&PIRLS Czech survey was used as a basis for a follow up longitudinal study, which made student initials available to us. ${ }^{11}$ The follow-up covered about $80 \%$ of the original TIMSS\&PIRLS sample because some of the originally sampled students were not in class during the follow-up survey or because a school refused to collaborate with the follow-up.

The Czech sample with both TIMSS and PIRLS test scores covers 4,438 pupils. From this data, we have dropped those pupils whose age was in the top or bottom $1 \%$ of the sample age distribution in order to eliminate from the analysis pupils who started school unusually early or late, such as pupils with learning disabilities who may have repeated grades. We also drop pupils who do not use the Czech language at home, in order to minimize any influence on our analysis of different naming patters for immigrants or minorities. Out of the remaining 3,704 pupils, we have name initials available for $81 \%$, i.e., for 3,003 tested students. ${ }^{12}$ Basic

${ }^{9}$ Whether a 15 -year-old is observed in the PISA data in grade 8 or 9 , i.e., before or after the selection into boarding schools in Denmark, depends on the age at elementary-school entry. We assume that age at school entry is independent of one's last name initial. This assumption is supported by analysis of Czech 4th graders' test scores in Section 3 and 4.

${ }^{10}$ The TIMSS\&PIRLS data collection is based on a two-stage random sample design, with a sample of schools drawn first and classes of students selected from each of the sampled schools.

${ }^{11}$ The longitudinal data collection effort at the Faculty of Education of Charles University, Prague is supported by a grant from the Czech Science Foundation No. P402/12/G130.

${ }^{12}$ The share of observations with name initials on the initial sample, before any exclusion of data, is identical. In total, we have 3,573 test scores with name information available. 
Table 1: 4th Graders' Characteristics

\begin{tabular}{lcc}
\hline \hline & Mean & Std. Dev. \\
\hline Age & 10.3 & 0.37 \\
Male dummy & 0.50 & 0.50 \\
Mathematics test score & 514.9 & 68.2 \\
Science test score & 541.1 & 68.8 \\
Reading test score & 549.8 & 58.9 \\
\hline \hline
\end{tabular}

Notes: Data corresponding to 3,003 pupils covered by the 2011 TIMSS\&PIRLS survey, who speak Czech at home and for whom name initials were available.

descriptive characteristics of the data are offered in Table $1 .^{13}$

Similar to the TIMSS\&PIRLS data, the PISA study provides mathematics and reading test scores. ${ }^{14}$ A unique feature of the 2009 Czech and Danish PISA sample is that it was possible to append the data with the first and last name initials of tested students. The Danish PISA sample covers 5,924 students. We omit 114 students from analysis who have entered school unusually early or late (or may have repeated grades) as we want to study school selection among relatively homogenous student groups. ${ }^{15}$ Out of the remaining 5,800

\footnotetext{
${ }^{13}$ The TIMSS\&PIRLS study (as well as the PISA study; see OECD, 2009) generates five versions of each test score, i.e., multiple estimates of the dependent variable of our analysis. These multiple estimates, which are sometimes referred to as 'plausible values', were developed to obtain consistent estimates of population characteristics in situations when rotated tests are used to increase the content coverage of tests without increasing the per-student testing time. The means of the dependent variables presented for our analysisready samples in Tables 1 and 2 are thus estimated using the pv routine (with full use of the sampling weights) developed for the analysis of 'plausible values' in TIMSS, PIRLS, and PISA data in Stata by Kevin Macdonald.

${ }^{14}$ The PISA study targets 15-year-old students attending educational institutions in grades 7 and higher and uses a two-stage stratified sample design where schools and students correspond to the first- and secondstage sampling units, respectively.

${ }^{15}$ Specifically, we exclude the 83 Danish students in the 10th grade, the 22 students in the 7 th grade, and the 19 students who already are in boarding continuation schools in the 8th grade.
} 
pupils, 885 are in the 8th grade in all-inclusive programs and the rest are in the 9th grade, of which $10 \%$ are in continuation schools.

Similarly, we start with Czech data on $(3,121)$ pupils in the 8 th and 9th grades, of which about $10 \%$ are enrolled in 'gymnazia' programs. ${ }^{16}$ In the next step, as with the TIMSS\&PIRLS data, we exclude from our PISA analysis those students who are likely to come from immigrant or minority households as we want to minimize the potential effect of different name patterns among immigrants on our analysis. ${ }^{17}$ This reduces the samples to 3,026 and 4,871 observations in the Czech Republic and Denmark, respectively.

Finally, we drop observations where name initials are not available. About $10 \%$ of Danish respondents are in the so-called 'opt-out register' as they requested that their data not be easily available for research purposes and this made coding of name initials difficult. The analysis-ready samples cover 2,934 Czech and 4,321 Danish PISA test scores. Table 2 presents descriptive characteristics of the Czech and Danish data for the all-inclusive and specialized programs separately; it supports the typical ordering of study achievements in the Czech Republic with students in academic programs scoring much higher, possibly because the schools select more talented students or because they teach better. The specialized Danish programs have only slightly higher means of test scores than the all-inclusive ones.

Our first task in the next section is to test the assumption made in Jurajda and Münich

\footnotetext{
${ }^{16}$ We thus do not use Czech data on 27 pupils in the 7 th grade and also on 2,787 10 th graders. We omit the large group in the 10th grade from the original PISA sample to maximize comparability between the two country analyses and also because these students are divided into five secondary-school types leading to small samples and noisy estimates. We also drop 137 students who attend the special schools for students with learning or other disabilities.

${ }^{17}$ Specifically, we exclude those students who report being born in another country or speaking a language at home that is different from the language of the test. In Denmark, where parents were also covered by the survey, we also exclude students whose parents report speaking a different language at home.
} 
Table 2: 8th and 9th Graders' Characteristics

\begin{tabular}{|c|c|c|c|c|}
\hline & \multicolumn{2}{|c|}{ Czech Republic } & \multicolumn{2}{|c|}{ Denmark } \\
\hline & Mean & Std. Dev. & Mean & Std. Dev. \\
\hline \multicolumn{5}{|c|}{ All-Inclusive Schools } \\
\hline Age & 15.7 & 0.23 & 15.7 & 0.28 \\
\hline Male dummy & 0.58 & 0.49 & 0.50 & 0.50 \\
\hline Mathematics test score & 462.2 & 78.9 & 507.4 & 84.4 \\
\hline Reading test score & 450.4 & 80.6 & 499.4 & 80.1 \\
\hline \multicolumn{5}{|c|}{ Specialized Schools } \\
\hline Age & 15.6 & 0.19 & 15.8 & 0.26 \\
\hline Male dummy & 0.48 & 0.50 & 0.46 & .50 \\
\hline Mathematics test score & 599.8 & 69.2 & 512.4 & 83.3 \\
\hline Reading test score & 572.7 & 59.0 & 500.7 & 82.9 \\
\hline
\end{tabular}

$\overline{\text { Notes: Data corresponding to 2,934 Czech and 4,321 Danish pupils }}$ covered by the PISA survey, who speak the language of the test at home and for whom name initials were available.

(2010) that ability and last-name initials are independent as of before tracking into selective schools in the Czech Republic. ${ }^{18}$ Second, in Section 4 we test whether a positive correlation arises between ability and one's numerical position in the alphabet through the process of student selection into separate tracks. If admission to selective schools is more likely for those sorted early in the alphabet, then such a positive correlation should arise among students admitted to highly selective schools and as a result also among students enrolled in easily accessible programs.

\footnotetext{
${ }^{18}$ We maintain the assumption that students do not adjust their application strategy based on their position in the alphabet. We are not aware of any public discussion of the issue of alphabet sorting in admission procedures in the Czech Republic outside of the brief mention of our 2010 publication in reference to university admissions. It appears that neither the students nor the schools consider this issue important.
} 


\section{Test Scores of 4 th Graders}

In this section we ask a simple question: Is there any correlation between last name initials and test scores of Czech pupils before selection into selective schools takes place. We ask this question using the TIMSS\&PIRLS data on test scores of 4th graders, i.e., one year before students may first apply for selective 'gymnazia' programs. Our strategy is simple: We regress test scores on a measure of one's position in the alphabet according to last name initial. Since we also have first name initial information available and since we know of no reason why first name initials should have any relationship to education outcomes, we also include the first name initial in our analysis in order to provide a 'natural' test of the use of last-name initials. ${ }^{19}$

We use two measures of one's position in the alphabet. The simplest measure is the numerical position (1 to 26) of one's first- and last-name initial. However, given that each letter in the alphabet represents a group of a different size, a more precise measure of one's position in an alphabetically ordered list consists of the fraction of the student cohort with last (first) name initial sorted higher in the alphabet. We estimate this 'cohort' position using the TIMSS\&PIRLS data (and using the PISA data in the next section). For the sake of comparability, both measures are scaled to give one's alphabetical percentile position ranging from (close to) 0 to $100 .^{20}$

We do not use TIMSS\&PIRLS sampling weights in our regression analysis and similarly, we do not use weights in our PISA regressions in the next section. While using weights is imperative when estimating population means and making cross-country comparisons, the

\footnotetext{
${ }^{19}$ In our earlier study, Jurajda and Münich (2010), we found last name initials to be predictive of highschool graduation test scores. We also found that first name initials did not affect these test scores, which was reassuring for our interpretation of the evidence.

${ }^{20}$ Both measures have a mean of 50 and a standard deviation of about 25 .
} 
motivation for the use of weights in regression analysis is less clear (Deaton, 1997, pp. 67-72). When regression parameters do not vary across students, unweighted OLS is always the most efficient unbiased estimator. Even if we thought of our regressions as estimating differences between 26 group means corresponding to the 26 letters of the alphabet, it is not clear that TIMSS\&PIRLS or PISA sampling weights lead to consistent mean estimates for each of these 26 groups, especially within school types and after the selection we applied to the original samples. Also, the variance increase involved in using weights within such small groups is large as weights vary by a factor of 60 in our data. Further, we use only the first 'plausible value' in every test dimension, similar to Hanushek et al. (2014). Working with only one of the values leads to unbiased parameter estimates; it ignores an imputation correction, which reflects test unreliability, but this correction relies on weights and is small in any case (OECD, 2009). While our regression analysis of PISA data is sensitive to the use of weights, there are no material differences between our weighted and unweighted TIMSS\&PIRLS regression estimates.

The results are presented in Table 3, where columns corresponds to regression specifications using the three available test scores as dependent variable. The two panels of the table then correspond to specifications using alternative measures of one's position in the alphabet. We obtain statistically precisely estimated zero parameters. ${ }^{21}$ We have also estimated identical regression specifications using the other four 'plausible values' of test scores, one at a time. We obtained estimates that were materially indistinguishable from those presented in Table 3 irrespective of the choice of the test score. None of the estimated coefficients on both last and first name initial position is even marginally statistically significant and they

\footnotetext{
${ }^{21}$ The inference is based on robust standard errors, i.e., the Huber-White unconditional heteroscedasticity correction, and is not sensitive to clustering of residuals at the level of last name initial (i.e., to allowing for potential correlations of student unobservables within name initial groups).
} 
Table 3: Czech 4th Graders' Test Scores and Alphabetical Position

\begin{tabular}{lccc}
\hline \hline Test Type & Mathematics & Science & Reading \\
& $(1)$ & $(2)$ & $(3)$ \\
\hline \multicolumn{4}{c}{ Alphabet Position Based on Letters' Numerical Order } \\
Last Initial & -0.023 & -0.025 & 0.012 \\
& $(0.083)$ & $(0.075)$ & $(0.066)$ \\
First Initial & -0.018 & 0.006 & -0.020 \\
& $(0.073)$ & $(0.065)$ & $(0.065)$ \\
\hline \multirow{4}{*}{ Alphabet Position Based on Cohort-Distribution Order } \\
Last Initial & -0.007 & -0.017 & 0.015 \\
& $(0.070)$ & $(0.063)$ & $(0.054)$ \\
First Initial & -0.039 & -0.015 & -0.044 \\
& $(0.061)$ & $(0.056)$ & $(0.056)$ \\
\hline \multirow{2}{*}{$\mathrm{N}$} & 3,003 & 3,003 & 3,003 \\
\hline \hline
\end{tabular}

Note: Results based on the TIMSS\&PIRLS survey. Regression are estimated using the first 'plausible value' and control for students' gender and age.

are economically negligible as well. Moving from the first to the last position in an alphabetically sorted list would result in score changes on the order of about one to two points, while the standard deviation of test scores is about 60 (see Table 1). Both the gender and the age controls (not shown) are strongly statistically significant in all regression specifications with the expected signs, i.e., boys scoring better than girls in mathematics and vice versa in reading. We have also estimated all specifications shown in Table 3 separately for those with age below and above the median age in our sample and for boys and girls separately. The estimated coefficients were statistically as well as economically fully similar across the various sub-groups. ${ }^{22}$ In sum, our evidence is supportive of the notion that there is no popu-

\footnotetext{
${ }^{22}$ We have also asked whether age of the surveyed 4th graders, which is determined by age at entry into
} 
lation relationship between last name initials and ability prior to early tracking into selective programs.

\section{Test Scores of 15-Year-Olds}

In this section, we use data on Czech 8th and 9th graders to test for the presence of abilityalphabet sorting with the $10 \%$ of the cohort studying in the academic 'gymnazia' programs from the 6th grade (knowing that there was no such sorting present through the 4th grade). ${ }^{23}$ Next, we separately ask the same question for 8th graders in Denmark, who all study in one type of schools, and for the Danish 9th graders, $10 \%$ of whom are enrolled in specialized 'Efterskoler' programs. Hence, we regress students' test scores on their position in the alphabet using the whole sample of test scores of Danish 8th graders and by school type in the 9th grade in Denmark and for both 8th and 9th grade in the Czech Republic. As in the previous section, our main focus is on last-name initials, but we also include a measure of one's first-name alphabetical position as a natural check on our approach since we know of no reason why first-name initials should affect admission chances. We also use the same two measures of one's alphabetical position we used in the previous section, apply the first 'plausible value', report robust standard errors, and do not weight the data.

Table 4 presents estimates of coefficients on first and last name initial position for the sample of 8th graders in Denmark. The evidence, based on students who all study in one type of program, is fully comparable to that presented in Table 3 for Czech 4 th graders in

elementary education, depends on one's last name initial. Consistent with the assumption made in n. 9, the alphabet-position parameters were equal to zero for all practical purposes and were not statistically significant.

${ }^{23}$ In effect, we assume that PISA test scores reflect ability at the time of admission into the current program. 
that all of the last-name coefficients are precisely estimated zeros. ${ }^{24}$ We thus cannot reject the hypothesis that there is no alphabet-ability relationship in either Denmark or the Czech Republic as long as all students study in one type of school.

\begin{tabular}{ccc} 
Table 4: Danish 8th Graders' Test Scores and Alphabetical Position \\
\hline \hline Test Type & Mathematics & Reading \\
& $(1)$ & $(2)$ \\
\hline Alphabet Position Based on Letters' Numerical Order \\
Last Initial & -0.003 & 0.055 \\
& $(0.148)$ & $(0.139)$ \\
First Initial & -0.124 & -0.211 \\
& $(0.160)$ & $(0.152)$ \\
\hline
\end{tabular}

Alphabet Position Based on Cohort-Distribution Order

\begin{tabular}{lcc} 
Last Initial & -0.021 & 0.013 \\
& $(0.122)$ & $(0.115)$ \\
First Initial & -0.086 & -0.170 \\
& $(0.126)$ & $(0.121)$ \\
\hline $\mathrm{N}$ & 553 & 553 \\
\hline \hline
\end{tabular}

Note: Results based on the PISA survey. Regressions are estimated using the first 'plausible value' and control for students' gender and age.

Next, we focus on Czech and Danish cohorts where about $10 \%$ of pupils have been selected into specialized programs. We find that under this selection, pupils sorted low in the alphabet display higher test scores (and presumably ability) than those with last names sorted high in the alphabet. Tables 5 and 6 bear out this claim.

\footnotetext{
${ }^{24}$ In contrast, the age and gender dummies have $\mathrm{t}$ ratios of 6 to 7 in the mathematics test regression. Inference is again not affected by allowing for clustering of residuals at the level of name initials. The first-name coefficients are large, but do not reach conventional levels of statistical significance.
} 
Table 5: Czech 8th and 9th Graders' Test Scores and Alphabetical Position

\begin{tabular}{lcccc}
\hline \hline & \multicolumn{2}{c}{ Specialized Schools } & \multicolumn{2}{c}{ All-Inclusive Schools } \\
\hline Test Type & Mathematics & Reading & Mathematics & Reading \\
& $(1)$ & $(2)$ & $(3)$ & $(4)$ \\
\hline Alphabet Position Based on Letters' Numerical Order & \\
Last Initial & $\mathbf{0 . 1 5 1}$ & 0.082 & $\mathbf{0 . 1 6 0}$ & $\mathbf{0 . 1 3 0}$ \\
& $(0.084)$ & $(0.082)$ & $(0.071)$ & $(0.037)$ \\
First Initial & 0.054 & 0.019 & 0.008 & 0.026 \\
& $(0.093)$ & $(0.083)$ & $(0.047)$ & $(0.068)$ \\
\hline \multirow{2}{*}{ Alphabet Position Based on Cohort-Distribution Order } & \\
Last Initial & $\mathbf{0 . 1 2 3}$ & 0.072 & $\mathbf{0 . 1 5 5}$ & $\mathbf{0 . 1 2 4}$ \\
& $(0.071)$ & $(0.067)$ & $(0.053)$ & $(0.032)$ \\
First Initial & 0.027 & -0.015 & -0.010 & -0.001 \\
& $(0.070)$ & $(0.068)$ & $(0.040)$ & $(0.047)$ \\
\hline $\mathrm{N}$ & 717 & 717 & 2,217 & 2,217 \\
\hline \hline
\end{tabular}

Note: Results based on the PISA survey. Regressions are estimated using the first

'plausible value' and control for students' gender and age. Bolded coefficients are statistically significant at the $10 \%$ level.

Table 5 presents regression coefficients of interest from regressions based on Czech pupils in the 8th and 9th grade. The two panels of each table correspond to the two measures of one's position in the alphabet. In the first two columns of the table, we present the name-initials coefficients estimated off the selective 'gymnazia' programs, while the next two columns present the mathematics- and reading-score regressions for the $90 \%$ of the cohort that stayed in all-inclusive lower-secondary education programs. Using the same table layout, the Danish regression estimates of interest based on 9th graders enrolled in the 'Efterskoler' and in all-inclusive programs are shown in Table 6. 
Table 6: Danish 9th Graders' Test Scores and Alphabetical Position

\begin{tabular}{lcccc}
\hline \hline & \multicolumn{2}{c}{ Specialized Schools } & \multicolumn{2}{c}{ All-Inclusive Schools } \\
\hline \multirow{2}{*}{ Test Type } & Mathematics & Reading & Mathematics & Reading \\
\multicolumn{4}{c}{ Alphabet Position Based on Letters' Numerical Order } & $(4)$ \\
\hline \multirow{2}{*}{ Last Initial } & $\mathbf{0 . 3 3 2}$ & $\mathbf{0 . 3 1 8}$ & $\mathbf{0 . 0 9 8}$ & $\mathbf{0 . 1 4 5}$ \\
& $(0.117)$ & $(0.135)$ & $(0.053)$ & $(0.054)$ \\
First Initial & -0.004 & -0.108 & $\mathbf{- 0 . 1 7 8}$ & $\mathbf{- 0 . 1 9 2}$ \\
& $(0.171)$ & $(0.137)$ & $(0.067)$ & $(0.053)$ \\
\hline \multirow{2}{*}{ Alphabet Position Based on Cohort-Distribution Order } & \\
Last Initial & $\mathbf{0 . 2 5 3}$ & $\mathbf{0 . 2 5 1}$ & $\mathbf{0 . 0 8 3}$ & $\mathbf{0 . 1 1 3}$ \\
& $(0.093)$ & $(0.107)$ & $(0.042)$ & $(0.042)$ \\
First Initial & -0.091 & -0.155 & $\mathbf{- 0 . 1 3 7}$ & $\mathbf{- 0 . 1 5 6}$ \\
& $(0.147)$ & $(0.118)$ & $(0.053)$ & $(0.044)$ \\
\hline $\mathrm{N}$ & 396 & 396 & 3,925 & 3,925 \\
\hline \hline
\end{tabular}

Note: Results based on the PISA survey. Regressions are estimated using the first

'plausible value' and control for students' gender and age. Bolded coefficients are statistically significant at the $5 \%$ level.

The parameter estimates, which are not sensitive to the use of alternative measures of alphabetical position, suggest that having a last name initial sorted low in the alphabet is correlated with high test scores in both mathematics and reading tests in both the selective and the non-selective schools in both countries. The last-name-initial effects are both statistically and economically significant: the gap between an 'A' and a ' $\mathrm{Z}$ ' student in the predicted mathematics test score in the Czech Republic is about 15 points, i.e. about one-fifth of the standard deviation of the test score. ${ }^{25}$

\footnotetext{
${ }^{25}$ We have conducted several additional sensitivity checks, including estimating the relationships for each
} 
The estimates for the small group of 'gymnazia' students are somewhat smaller in the Czech Republic when based on the reading rather than the mathematics test score. Further, in regressions based on the Danish students in the 9th grade in all-inclusive programs, we obtain a puzzling statistically significant negative estimate of the effect of the first-name-initial position. This negative coefficient represents the sole violation of our natural specification test as all other first-name-initial coefficients in our analysis are not statistically significant. ${ }^{26}$

Overall, we find that students with surnames sorted low in the alphabet do achieve higher test scores on average and that this sorting "effect" is present only when students undergo some degree of selection into specialized programs. As we can think of no alternative explanation, and since our PISA- and TIMSS\&PIRLS-based findings are in accord with those presented in Jurajda and Münich (2010) and based on Czech upper-secondary-school graduation exams, we find these results strongly consistent with the ability-alphabet sorting hypothesis and therefore suggestive of the presence of alphabet-based admission procedures.

\section{Conclusions}

Economists have explored the information content of first or last names on the labor-market (Bertrand and Mullainathan, 2004; Collado et al., 2008, Biavaschi et al., 2013) and the importance of alphabetical sorting for scientific citations (Einav and Yariv, 2006) and election outcomes (Ho and Imai, 2008). However, behavioral consequences of default alphabetical sorting for ranking generation by evaluators faced with many subjects to assess has received

gender separately, and found little sensitivity. We have also asked whether the age of the tested students (and, hence, their age at school entry) is related to their alphabetical position and found no statistically significant effects consistent with the assumption made in note n. 9 .

${ }^{26}$ In Jurajda and Münich (2010), we also obtained one puzzling negative coefficient estimate of the firstname initial position effect, possibly corresponding to type-I inference error. 
little attention to date.

In this paper, we use student test scores from two international data collection efforts from two countries to show that as long as students study in one all-inclusive school type, there appears to be no relationship between their test scores and alphabetical position according to last name initial. However, when selection into specialized programs takes place, we detect strong correlations between students' alphabetical position and test scores, consistent with the use of alphabetically sorted lists in the admission process.

These findings corroborate those provided in Jurajda and Münich (2010) based on different types of data, and they also stand our natural test of asking about the effect of one's first-name-initial position in the alphabet, which we find, with one exception, to play no role. We do not provide direct evidence on which schools may be using alphabetically sorted applicant lists or how an alphabetical 'treatment' may occur in schools' admission policies. Yet, we believe that the combination of our findings and the absence of an alternative explanation lend our hypothesis credibility. Future research using large datasets can test our hypothesis using secondary-school data from several countries or can collect data on the nature of the application procedures used by individual schools to provide direct evidence.

Should our interim interpretation of the empirical findings be correct, there would be a non-negligible negative effect of apparently non-discriminatory practices for individuals with last names towards the bottom of the alphabet. The issue with the repeated use of the alphabet to provide a non-discriminatory sorting in many settings is that one's last-nameinitial 'lottery ticket' is drawn once for life or for long parts of life, i.e., for many potential lotteries. Future work may thus consider alphabetical sorting effects in access to rationed goods, such as public housing or body organs for transplant. 


\section{Bibliography}

Bertrand, M., \& Mullainathan, S. (2004). Are Emily and Greg more employable than Lakisha and Jamal? A field experiment on labor market discrimination. American Economic Review, 94(4), 991-1013.

Biavaschi, C., Giulietti, C., and Z. Siddique (2013) The Economic Payoff of Name Americanization. IZA Discussion Paper No. 7725.

Collado, M.D., Ortín, I.O., \& Romeu, A. (2008). Surnames and social status in Spain. Investigaciones Economicas, 32(3), 259-287.

Deaton, A. (1997). Analysis of Household Surveys. Johns Hopkins University Press.

Einav, L., \& Yariv, L. (2006). What's in a surname? The effects of surname initials on academic success. Journal of Economic Perspectives, 20 (1), 175-188.

Filer, R.K., \& Münich, D. (2013). Responses of private and public schools to voucher funding. Economics of Education Review, 34: 269-285.

Fryer, R.G., Jr., \& Levitt, S. (2004). The causes and consequences of distinctively black names. Quarterly Journal of Economics, 119(3), 767-805.

Hanushek E.A., Schwerdt, G., Wiederhold, S. \& Woessmann, L. (2014). Returns to Skills Around the World: Evidence from PIAAC. NBER Working Paper No. 19762.

Ho, D.E., and K. Imai (2008). Estimating Causal Effects of Ballot Order from a Randomized Natural Experiment: The California Alphabet Lottery, 1978-2002. Public Opinion Quarterly, 72(2): 216-240.

Jurajda, Š. a D. Münich (2010). Admission to Selective Schools, Alphabetically. Economics of Education Review, 29 (6): 1100-1109.

Moldanová, D. (2004). Naše př́jmení [Our Surnames], Pankrac, Prague, 2nd edition.

OECD (2007). Education at a Glance, OECD, Paris. 
OECD (2009). Analyses with Plausible Values, in PISA Data Analysis Manual: SPSS, Second Edition, OECD, Paris.

OECD (2010). PISA 2009 Results: What Makes a School Successful? Resources, Policies and Practices, Volume IV. OECD, Paris.

Simonsohn, U., and F. Gino (2013). Daily Horizons: Evidence of Narrow Bracketing in Judgment from 10 years of MBA-admission Interviews. Psychological Science, 24 (2): $219-224$.

Tversky, A., and D. Kahneman (1971). Belief in the law of small numbers, Psychological Bulletin, 76(2), 105-110.

UIV - Ústav pro informace ve vzdělávání [Institute for Information on Education] (2010). Krajská ročenka školství 2009 [Regional yearbook of education 2009], Prague.

van Ours, J., \& Ginsburgh, V.A. (2003). Expert opinion and compensation: evidence from a musical competition. American Economic Review, 93(1), 289-296.

van Praag, M., \& van Praag, B.M.S. (2008). The benefits of being economics professor A (rather than Z). Economica, 75, 782-796.

Šimíková, I., Navrátil, P., \& Winkler, J. (2004). Evaluation of programs aiming at lowering the risk of social exclusion of the Roma minority. Research Institute for Labour and Social Affairs, Prague and Brno. 


\section{Working Paper Series}

ISSN 1211-3298

Registration No. (Ministry of Culture): E 19443

Individual researchers, as well as the on-line and printed versions of the CERGE-EI Working Papers (including their dissemination) were supported from institutional support RVO 67985998 from Economics Institute of the ASCR, v. v. i.

Specific research support and/or other grants the researchers/publications benefited from are acknowledged at the beginning of the Paper.

(c) Štěpán Jurajda and Daniel Münich, 2014

All rights reserved. No part of this publication may be reproduced, stored in a retrieval system or transmitted in any form or by any means, electronic, mechanical or photocopying, recording, or otherwise without the prior permission of the publisher.

Published by

Charles University in Prague, Center for Economic Research and Graduate Education (CERGE) and

Economics Institute of the ASCR, v. v. i. (EI)

CERGE-El, Politických vězňů 7, 11121 Prague 1, tel.: +420 224005 153, Czech Republic.

Printed by CERGE-EI, Prague

Subscription: CERGE-EI homepage: http://www.cerge-ei.cz

Phone: + 420224005153

Email: office@cerge-ei.cz

Web: http://www.cerge-ei.cz

Editor: Marek Kapička

The paper is available online at http://www.cerge-ei.cz/publications/working_papers/.

ISBN 978-80-7343-313-0 (Univerzita Karlova. Centrum pro ekonomický výzkum a doktorské studium)

ISBN 978-80-7344-306-1 (Akademie věd České republiky. Národohospodářský ústav) 
CERGE-EI

P.O.BOX 882

Politických vězňů 7

11121 Praha 1

Czech Republic http://www.cerge-ei.cz 